| Dossiê: Impactos e Repercussões Socioambientais de Empreendimentos na Pan-Amazônia| DOI: http://dx.doi.org/10.18764/2446-6549.e202005

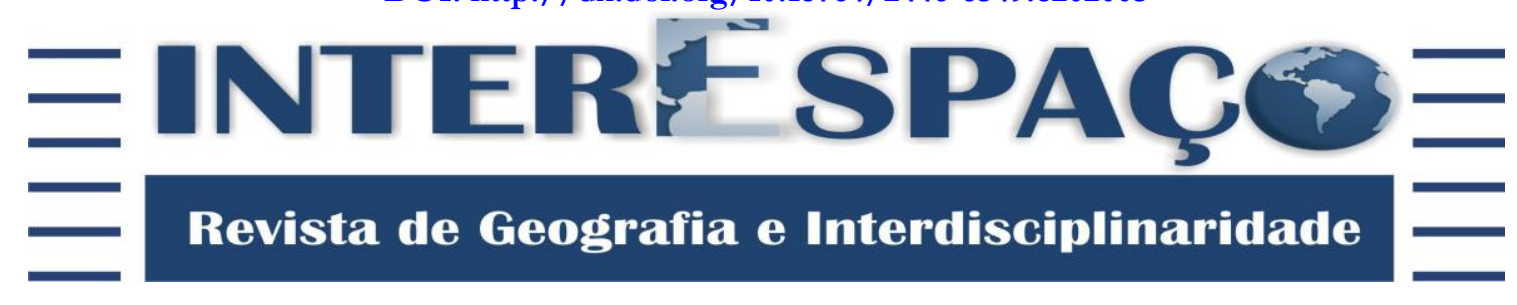

\title{
O PROJETO DE ASSENTAMENTO CONJUNTO TERRANOVA I NA BORDA MERIDIONAL DA AMAZÔNIA MATO-GROSSENSE: efeitos territoriais da ocupação
}

\author{
THE TERRANOVA I JOINT SETTLEMENT PROJECT ON THE \\ SOUTHERN EDGE OF MATO GROSSO AMAZON: territorial effects \\ of occupation
}

\section{EL PROYECTO DE ASENTAMIENTO CONJUNTO TERRANOVA I EN EL BORDE MERIDIONAL DE LA AMAZONIA MATO-GROSSENSE: efectos territoriales de la ocupación}

\begin{abstract}
José Aldair Pinheiro
Mestre e Doutorando em Ciências Ambientais pela Universidade do Estado de Mato Grosso UNEMAT. Docente formador pelo Centro de Formação e Aperfeiçoamento de Professores (CEFAPRO) da Secretaria de Estado de Educação de Mato Grosso (SEDUC-MT). jpinheiral@gmail.com / http://orcid.org/0000-0002-0715-424
\end{abstract}

\section{Aumeri Carlos Bampi}

Filósofo, Doutor em Filosofia e Ciências da Educação pela Universidade de Santiago de Compostela - USC/Espanha. Pós-doutor pela Universidade de São Paulo - USP. Docente da Faculdade de Educação e Linguagem e dos Programas de Pós-Graduação em Ciências Ambientais

(PPGCA) e Geografia (PPGGEO) da Universidade do Estado de Mato Grosso - UNEMAT. aumeribampi@gmail.com / http://orcid.org/0000-0002-3410-9376

\section{Carlos Alberto Franco da Silva}

Geógrafo, Mestre e Doutor em Geografia pela Universidade Federal do Rio de Janeiro - UFRJ. Pós-doutor pela Universidade de São Paulo - USP. Professor Associado IV e do Programa de Pósgraduação em Geografia da Universidade Federal Fluminense - UFF. carlosfds1963@gmail.com / http://orcid.org/0000-0002-3198-2188

Recebido para avaliação em 30/06/2020; Aceito para publicação em 10/11/2020.

\section{RESUMO}

O estudo analisa a relação sociedade/natureza e os efeitos territoriais decorrentes do assentamento via colonização oficial-particular na Amazônia, no Projeto Terranova I, na região norte de Mato Grosso. Situado no âmbito das políticas nacionais integracionistas da década de 1970, surgiu como resposta às demandas de campesinos gaúchos e sem-terra, em face dos problemas da modernização da agricultura sulista. A metodologia adotada se apoiou em entrevistas, registro de narrativas e observações de campo. Os resultados apontam que o desmatamento civilizador conduzido pelo pragmatismo economicista ocasionou a total supressão da floresta originária, diminuiu a fauna e adulterou os recursos hídricos na área. O solo, destinado à agricultura familiar, poucos anos depois, teve uso suplantado pela monocultura de pastagens à pecuária bovina extensiva. Registra-se que houve pouco amparo governamental, ausência de assistência técnica e de gestão ambiental, o que potencializou a apropriação com intensa degradação e graves implicações ecológicas e socioeconômicas. Conclui-se que, passadas quatro décadas, o assentamento rural revelou insustentabilidade das práticas produtivas e problemas de fixação do camponês à terra. 
|O Projeto de Assentamento Conjunto Terranova I na borda meridional da Amazônia MatoGrossense: efeitos territoriais da ocupação|

|José Aldair Pinheiro | Aumeri Carlos Bampi | Carlos Alberto Franco da Silva |

Palavras-chave: Amazônia; Assentamento Rural; Degradação Ambiental; Fronteira Agrícola.

\begin{abstract}
The study analyzes the society/nature relationship and the territorial effects resulting from the settlement via official-private colonization in the Amazon, in the Terranova I Project, in the northern region of Mato Grosso. Situated within the scope of the national integrationist policies of the 1970s, it emerged as a response to the demands of gauchos and landless peasants, in the face of the problems of the southern agriculture modernization. The adopted methodology was based on interviews, recording of narratives and field observations. The results show that civilizing deforestation driven by economicist pragmatism caused the total suppression of the original forest, reduced fauna and adulterated water resources in the area. The soil, destined for family farming, a few years later, had its use supplanted by the monoculture of pastures to extensive cattle ranching. It is noted that there was little government support, absence of technical assistance and environmental management, which increased ownership with intense degradation and serious ecological and socioeconomic implications. It is concluded that, after 4 decades, the rural settlement revealed unsustainability of the productive practices and problems of fixation the peasant to the land.
\end{abstract}

Keywords: Amazon; Rural Settlement; Environmental Degradation; Agricultural Frontier.

\title{
RESUMEN
}

El estudio analiza la relación sociedad/naturaleza y los efectos territoriales resultantes del asentamiento a través de la colonización oficial-privada en la Amazonía, en el Proyecto Terranova I, en la región norte de Mato Grosso. Situada en el ámbito de las políticas nacionales integracionistas de la década de 1970, surgió como respuesta a las demandas de los gauchos y campesinos sin tierra, ante los problemas de modernización de la agricultura sureña. La metodología adoptada se basó en entrevistas, registro de narrativas y observaciones de campo. Los resultados muestran que la deforestación civilizadora impulsada por el pragmatismo económico provocó la supresión total del bosque original, la reducción de la fauna y la adulteración de los recursos hídricos de la zona. El suelo, destinado a la agricultura familiar, unos años más tarde, tuvo su uso suplantado por el monocultivo de pastos a la ganadería extensiva. Se observa que hubo poco apoyo gubernamental, ausencia de asistencia técnica y manejo ambiental, lo que aumentó la apropiación con una degradación intensa y graves implicaciones ecológicas y socioeconómicas. Se concluye que, luego de 4 décadas, el asentamiento rural reveló insostenibilidad de las prácticas productivas y problemas de fijación del campesino a la tierra.

Palabras clave: Amazonía; Asentamiento Rural; Degradación Ambiental; Frontera Agrícola.

\section{INTRODUÇÃO}

A partir do século XX, principalmente após a década de 1970, a Amazônia passou por intenso processo de transformação socioespacial influenciado pela geopolítica do Estado, Estados-nações e ação das corporações. Esse cenário se expressava por meio do processo de integração física e econômica da Amazônia na divisão regional do trabalho em escalas nacional e internacional e na conquista geopolítica do beartland brasileiro.

Para tanto, o planejamento estratégico do Estado lançou diretrizes em direção à delimitação de uma região-programa - no âmbito da Superintendência do Plano de Valorização Econômica da Amazônia (SPVEA) - e aos requisitos da integração da Amazônia à economia nacional diante do recuo do extrativismo do látex e da descoberta de 
|O Projeto de Assentamento Conjunto Terranova I na borda meridional da Amazônia MatoGrossense: efeitos territoriais da ocupação|

|José Aldair Pinheiro | Aumeri Carlos Bampi | Carlos Alberto Franco da Silva |

recursos minerais e do potencial de exploração madeireira e expansão agropecuária.

A fronteira demandava fluidez do espaço na tradução da conexão da Amazônia à urbanização brasileira via extensão da rede urbana e técnica. Além disso, a constituição de um mercado regional de mão de obra disponível ao capital anunciava programas de colonização e propaganda oficial para atração de migrantes de áreas de conflitos fundiários, sobretudo nordestinos e sulistas, decorrentes da modernização agrícola conservadora, dolorosa e autoritária do campo brasileiro. Assim, a partir de 1960, a Amazônia brasileira se tornou uma questão nacional que se acoplava aos interesses imperialistas internacionais e de empresas estatais e à Doutrina de Segurança Nacional proposta pela Escola Superior de Guerra.

A manifestação geográfica da natureza das transformações regionais se verificam no passivo ambiental, nos conflitos fundiários decorrentes da imposição de uma racionalidade tecnoprodutiva capitalista diante de territorialidades tradicionais, na constituição de uma rede urbana rodoviária, na implantação de uma logística de redes de energia elétrica, comunicações e de transporte, na constituição de sistemas técnicos de vigilância e controle das fronteiras sul-americanas, no recuo das oligarquias regionais tradicionais em favor de novos atores hegemônicos (Forças Armadas, corporações internacionais, empresas imobiliárias e latifundiários sulistas, sobretudo), na urbanização e industrialização de localidades estratégicas (Zona Franca de Manaus e company towns de projetos míneroindustriais). Assim como, na ideologia geográfica propagandista de acesso à terra para os migrantes oriundos em grande parte de um campesinato expropriado de uma estrutura agrária latifundiária do país, extremamente desigual e concentrada. Enfim, os impactos da modernização autoritária sobre a Amazônia são inúmeros.

Neste estudo, a recuperação de um projeto de assentamento rural se volta à leitura contemporânea do legado das políticas territoriais do Estado na chamada "ocupação" demográfica-produtiva da Amazônia por meio da expansão da fronteira agrícola camponesa.

É interessante observar que, passados mais de 50 anos, a relação entre meio ambiente, agricultura familiar e geopolítica se unem num corpo estratégico de afirmação do Estado e dos interesses capitalistas. O resgate de um empreendimento que movimentou o campesinato pela ação das políticas federais nos remete à problemática geopolítica de inserção da Amazônia na dinâmica do capital internacional e nos coloca diante dos desafios atuais da nova racionalidade socioambiental alternativa aos interesses do grande capital.

A estratégia de ocupação com pequenos produtores migrantes ocorreu por meio de assentamentos rurais conduzidos pelo Instituto Nacional de Colonização e Reforma 
|O Projeto de Assentamento Conjunto Terranova I na borda meridional da Amazônia Mato-

Grossense: efeitos territoriais da ocupação|

|José Aldair Pinheiro | Aumeri Carlos Bampi | Carlos Alberto Franco da Silva |

Agrária (INCRA), cooperativas e por diversos projetos de colonização particulares promovidos por empresas imobiliárias. Uma das porções regionais da Amazônia envolvida com a abertura da fronteira via colonização se localizava nas bordas meridionais do bioma, a Mesorregião Norte de Mato Grosso, área dominada por floresta ombrófila e diretamente interligada ao eixo rodoviário da BR-163 (rodovia federal Cuiabá-Santarém).

A rodovia servia como parte da instrumentalização do território amazônico para fins de constituição de núcleos urbanos e de apoio à colonização. De fato, colonizaçãoassentamento rural-rodovia-urbanização-cidade formava uma estratégia espacial articulada à projeção geopolítica da urbanidade capitalista sobre racionalidades territoriais rurais das populações tradicionais e preparava o espaço amazônico para os interesses das Forças Armadas e das corporações, valendo-se do anseio do campesinato por acesso à terra. Em efeito, não só as populações tradicionais e seus territórios sofreram, mas também os recursos hídricos, fauna e flora. A (re)ocupação da Amazônia cobrava seu preço em perdas de espaços de vida às comunidades nativas, conflitos fundiários e destruição do bioma.

A geopolítica estatal-militar, por meio do INCRA, inscrevia os projetos de colonização via migração como um dos pilares do Programa de Integração Nacional (PIN), elaborado no âmbito do I Plano Nacional de Desenvolvimento (I PND). Nesse sentido, milhares de habitantes das regiões Sul, Sudeste e Nordeste adentraram ao Centro-Oeste e à Amazônia por meio de rodovias de integração nacional, em especial entre as décadas de 1960 e 1980, tais como a rodovia Cuiabá-Santarém (BR-163), Cuiabá-Porto Velho (BR364), Transamazônica (BR-230) e Belém-Brasília (BR-153).

Neste trabalho, analisa-se a relação sociedade-natureza inscrita no Projeto de Assentamento Conjunto Terranova I (PAC Terranova) e seus efeitos territoriais decorrentes da política de colonização oficial-particular na Amazônia. A denominação assentamento conjunto resultava da parceria entre o INCRA e Cooperativa Agropecuária Mista Canarana (COOPERCANA).

Localizada no bioma da Amazônia mato-grossense, a área de estudo (Figura 1) é constituída pelo PAC Terranova I, que compreende o espaço das agrovilas Esteio, Planalto, Nonoai e Guarita, instaladas na fase inicial do PAC Terranova I, em 1978. 
|O Projeto de Assentamento Conjunto Terranova I na borda meridional da Amazônia MatoGrossense: efeitos territoriais da ocupação|

|José Aldair Pinheiro | Aumeri Carlos Bampi | Carlos Alberto Franco da Silva |

Figura 1 - Localização da área de estudo

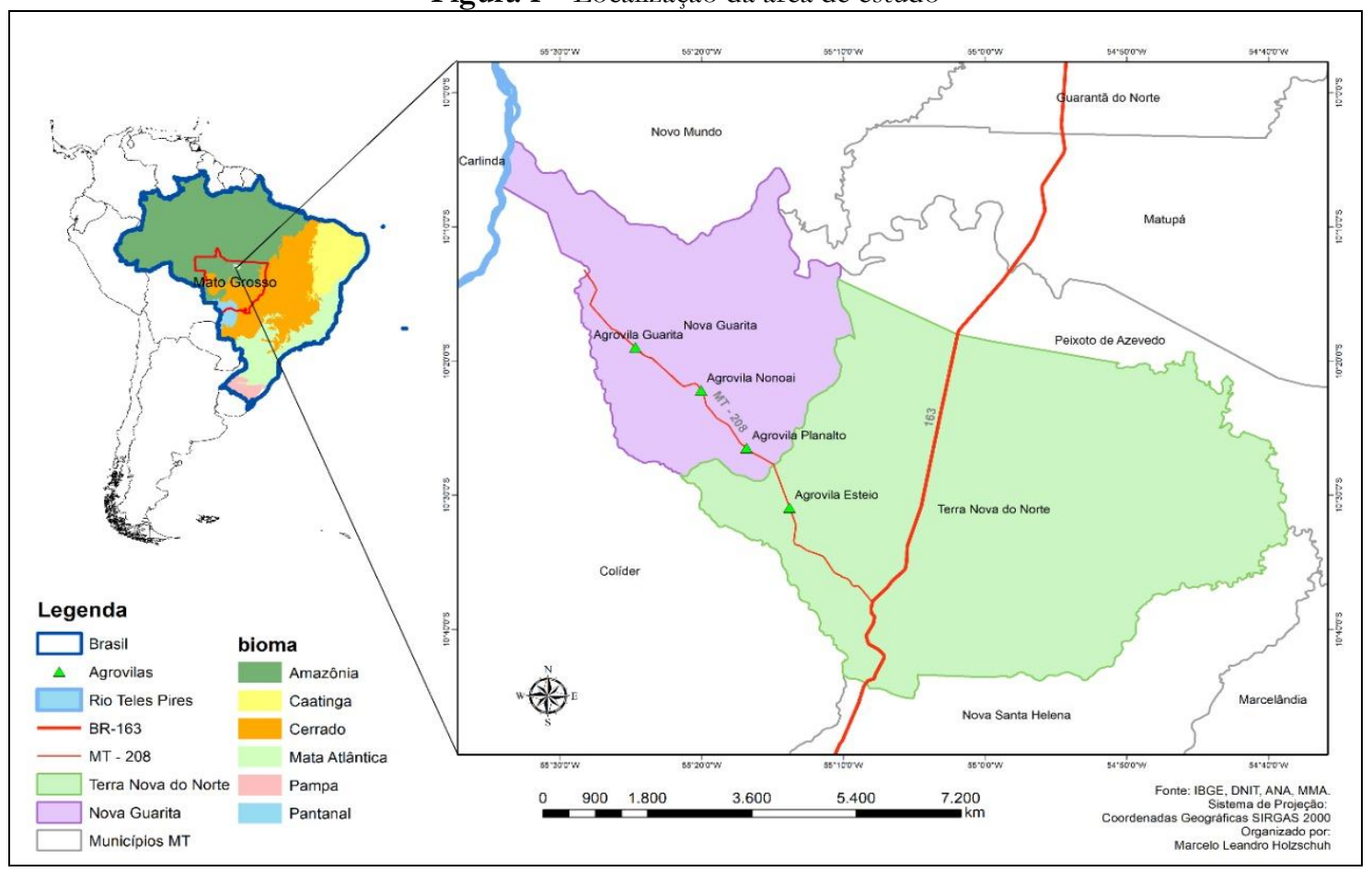

Elaboração: Marcelo Leandro Holzschuh (2020).

As comunidades rurais pesquisadas e suas propriedades estão situadas ao longo da rodovia MT-208 que se inicia no município de Terra Nova do Norte e atravessa o município de Nova Guarita (MT). A agrovila Esteio está situada no município de Terra Nova do Norte e as demais situam-se no município de Nova Guarita. A agrovila Guarita, por exemplo, deu origem ao município de Nova Guarita, oriundo do desmembramento do município de Terra Nova do Norte (1993), como consequência do crescimento populacional decorrente do garimpo do ouro na região do entorno. À época da implantação, em 1978, as agrovilas tinham como sede administrativa municipal a cidade de Chapada dos Guimarães, localizada a mais de $700 \mathrm{~km}$ de distância. Em linhas gerais, as agrovilas estudadas foram as primeiras executadas no projeto. $\mathrm{O}$ assentamento envolveu $\mathrm{O}$ governo federal, e as terras foram adquiridas pelos agricultores com financiamento junto ao Banco do Brasil (CASTRO et al., 2002; SCHWANTES, 1988).

A metodologia, para fins de respostas ao objetivo proposto, revela uma operacionalização por meio da revisão bibliográfica da abertura da fronteira amazônica, a partir de 1970. Desse ponto, o estudo se voltou para o caso do PAC Terranova I. Destarte, pesquisas de campo foram realizadas na localidade do PAC. Foram realizadas 22 entrevistas com membros das comunidades camponesas que possibilitaram revelar o histórico do uso do espaço e as relações dos radicados com a realidade ambiental. As pesquisas de campo e entrevistas foram realizadas nas propriedades rurais, nos anos de 2016, 2017 e 2018, com a 
|O Projeto de Assentamento Conjunto Terranova I na borda meridional da Amazônia MatoGrossense: efeitos territoriais da ocupação|

|José Aldair Pinheiro | Aumeri Carlos Bampi | Carlos Alberto Franco da Silva |

participação de 16 famílias que estiveram desde o início do assentamento. A pesquisa contou ainda com o uso de registro fotográfico e produção cartográfica.

\section{O PROJETO DE COLONIZAÇÃo TERRANOVA NO NORTE MATO- GROSSENSE}

Com o Estatuto da Terra, de 1964, o governo militar criou amplo aparato jurídico, político, institucional e ideológico para implantar e desenvolver a expansão econômica capitalista, avançando sobre as fronteiras do Centro-Oeste e Amazônia. Um desses aparatos foi promover a ocupação com projetos de colonização oficial e particular sob um modelo de apropriação dos recursos florestais e minerais e implantação da agricultura e da pecuária.

No estado de Mato Grosso, o governo federal incentivou e promoveu tanto a colonização oficial quanto a privada. Os projetos de colonização privada predominaram no território, mas contaram com apoio estatal federal através do INCRA e estadual através da Companhia de Desenvolvimento de Mato Grosso (CODEMAT), responsáveis pela localização e organização da ocupação em áreas de terras devolutas. Esses órgãos auxiliavam ainda o repasse de áreas às empresas, companhias e cooperativas colonizadoras para negociação. Estas, com a concessão das terras recebidas do Estado se incumbiam da venda dos lotes e de montar a infraestrutura para assentar os camponeses recrutados nas regiões Sul, Nordeste e Sudeste. Para isso, recebiam incentivos e favorecimento público (BARROZO, 2008).

No âmbito geopolítico do PIN, tanto os projetos agropecuários financiados pela SUDAM quanto os projetos de colonização revelavam um padrão seletivo de localidades que acompanhava os principais eixos logísticos de circulação rodoviária e fluvial de Mato Grosso e as diretrizes gerais do Estado e dos interesses das empresas.

No norte mato-grossense, os projetos de colonização oficial foram implantados a partir de 1978. Quando criados pelo INCRA, os PACs (Projetos de Assentamentos Conjuntos) consistiam em somar ações oficiais e a iniciativa de cooperativas agrícolas. A proposta implementou, de início, seis projetos: Terranova (1978), Peixoto de Azevedo, Ranchão (1980), Braço Sul, Carlinda e Lucas do Rio Verde (1981) (CASTRO et al., 2002).

O projeto Terranova foi composto por famílias oriundas do estado Rio Grande do Sul, que se encontravam em disputa por terra com indígenas Kaingang, nos municípios de Nonoai, Planalto e Tenente Portela. Em meados da década de 1970, os conflitos se intensificaram, o que levou as autoridades à proposição da transferência a novos espaços. 
|O Projeto de Assentamento Conjunto Terranova I na borda meridional da Amazônia MatoGrossense: efeitos territoriais da ocupação|

|José Aldair Pinheiro | Aumeri Carlos Bampi | Carlos Alberto Franco da Silva |

Na situação em que se encontrava o grupo de camponeses gaúchos, o acesso à terra era uma questão de sobrevivência e poucas alternativas havia: ir para a periferia das cidades buscar trabalho, participar de algum movimento social ou migrar a outras regiões.

A migração precarizada inscrevia uma luta por terra-território-ambiente para fins de afirmação do direito à moradia, sustento familiar e desenvolvimento das atividades agrícolas. Assim, as famílias de pequenos agricultores foram retiradas das áreas de conflitos e incorporadas ao processo de expansão da fronteira agrícola no Centro-Oeste e na Amazônia.

No contexto de conflitos agrários e de expansão dos movimentos sociais e defesa da reforma agrária, a oferta de terras em quantidades maiores a que os agricultores estavam acostumados a lidar em suas áreas de origens no Sul foi uma atraente proposta. Lideranças foram chamadas a conhecer os planos por meio da visitação aos locais dos projetos (MIRANDA, 1990).

A partir daí, centenas de famílias, em constantes conflitos nas reservas indígenas do Rio Grande do Sul, foram convencidas a aderir aos projetos de assentamento no Mato Grosso. Além da tensão social, criar e sustentar os filhos era fator preponderante diante da falta de perspectivas econômicas. Outro estímulo à migração foi a propaganda de acesso à terra produzida pelo governo federal. O menor ritmo de expansão da economia nacional, no final da década de 1970, e a modernização da agricultura sulista ampliavam o desemprego rural, a valorização das terras e minimizavam as possibilidades de acesso à terra no Sul do país, assinala Haesbaert (1996).

Havia ainda uma situação singular. Muitas famílias de agricultores gaúchos retiradas de áreas conflitivas com indígenas se encontravam acampadas no Parque de Exposição Internacional em Esteio/RS, situado na zona urbana da grande Porto Alegre. Elas haviam sido expulsas pelos indígenas Kaingang das terras invadidas. O governo militar, para fins de monitoramento e controle, os alocou no parque, a $400 \mathrm{~km}$ do local de conflito.

A proximidade da realização da Exposição Internacional de Animais, Máquinas, Implementos e Produtos Agropecuários (EXPOINTER - Esteio, RS) provocou a necessidade da remoção das famílias acampadas no parque. Ironicamente, o local que provisoriamente os abrigava era a representação máxima de sua expulsão do campo, pois os negócios da exposição giravam em torno da agricultura empresarial moderna, que se instalara com intensa mecanização e utilização de insumos exógenos, típicos da agricultura comercial, evidenciando uma ruralidade em profunda transformação e excludente.

Diante da situação, o Ministério do Interior articulou com a COPERCANA a rápida transferência das famílias ao norte mato-grossense. A cooperativa tinha respaldo 
|O Projeto de Assentamento Conjunto Terranova I na borda meridional da Amazônia MatoGrossense: efeitos territoriais da ocupação|

|José Aldair Pinheiro | Aumeri Carlos Bampi | Carlos Alberto Franco da Silva |

junto ao governo federal pelo desenvolvimento de projetos de colonização no estado do Pará, Amazonas e nos municípios de Barra do Garças e Canarana no estado de Mato Grosso (CASTRO et al., 2002; SCHWANTES, 1988).

A cooperação estratégica entre COOPERCANA e o INCRA transferiu de imediato as 85 famílias acampadas que foram destinadas à primeira agrovila (Esteio). A cooperativa contratou transporte aéreo para a locomoção das famílias. A demanda desse transporte resultou na então chamada "ponte aérea da miséria (Porto Alegre-Cuiabá)", dada a situação de penúria das famílias. A continuidade do trajeto de Cuiabá até o assentamento foi realizada com ônibus fretados. Schwantes (1988) relata que muitas pessoas, principalmente crianças e idosos, encontravam-se mal nutridas e fragilizadas física e psicologicamente. No decorrer da viagem, muitos ficaram pelo caminho, precisando de atendimento médico hospitalar, carecendo do apoio da cooperativa. Isso elevou os custos da transferência, atrasou a realocação, gerou insatisfação e sinalizou a desistência de outros grupos que seriam destinados às agrovilas da primeira fase do projeto.

O processo também foi difícil em razão de ter de deixar os locais de origem e por não ser uma opção livre. Era a única oportunidade de acesso à terra nas condições sociopolíticas da sociedade brasileira à época sob o jugo ditatorial. Não era fácil deslocar-se de suas raízes culturais em situação de extrema pobreza, de dependência e sem portar recursos a um lugar situado a mais de $2.000 \mathrm{~km}$ da origem, desconhecido em termos de biodiversidade e ecossistemas, com precária interligação rodoviária e de comunicação e sem qualquer estrutura de saúde, educação e de convívio comunitário.

No contexto do projeto havia ainda a problemática situação das famílias que ocupavam reservas indígenas localizadas nos municípios de Planalto e Tenente Portela e que também necessitavam ser transferidas. A questão agrária gaúcha, no seio da modernização conservadora da agricultura brasileira, abria espaço para um enorme movimento de populações excluídas que acabaria por consolidar parte da colonização da Amazônia (HAESBAERT, 1996). Assim se inseria a migração camponesa em direção à primeira etapa do PAC Terranova I.

O assentamento foi idealizado a partir de uma experiência de ruralidade vivenciada por Norberto Schwantes, jornalista e pastor luterano durante sua estada na Alemanha (SCHWANTES, 1989), que era presidente da COOPERCANA à época. A ideia foi adaptada e adotada junto ao INCRA para a realização do assentamento conjunto.

O PAC Terranova I previa 1.200 famílias. No entanto, no ano de 1978, foi possível assentar apenas 416 famílias nas agrovilas planejadas, totalizando 2.266 pessoas (CASTRO et al., 2002). A razão remonta a problemas na execução do projeto e também por conta das 
|O Projeto de Assentamento Conjunto Terranova I na borda meridional da Amazônia MatoGrossense: efeitos territoriais da ocupação|

|José Aldair Pinheiro | Aumeri Carlos Bampi | Carlos Alberto Franco da Silva |

mudanças nas políticas do governo federal, que havia iniciado uma série de concessões a empresas imobiliárias de colonização privada na região norte mato-grossense, tornando as terras amazônicas uma mercadoria e, consequentemente, diminuindo o papel do INCRA na movimentação dos camponeses e constituição de assentamentos oficiais.

\section{As agrovilas e o período inicial no assentamento}

Ao chegar ao assentamento, os agricultores eram estabelecidos nas agrovilas, previstas para funcionar como núcleo urbano secundário [urbanismo rural proposto pelo governo militar], pois o núcleo principal ficou sendo a cidade de Terra Nova, planejada dentro do projeto original (CASTRO et al., 2002, p. 72). Posteriormente, o núcleo central, a cidade de Terra Nova do Norte, foi transferido para um local às margens da rodovia BR163.

As agrovilas foram os primeiros espaços de moradia, uma vez que os lotes rurais para assentamento definitivo se encontravam em demarcação. Os camponeses encontraram as casas ainda em construção (Figura 2), assim como as edificações de espaços comunitários. As famílias ficaram instaladas de forma precária e improvisada em barracas de lona plástica por meses, até que as habitações de madeira (casas) fossem finalizadas.

Figura 2 - Chegada das primeiras famílias na Agrovila Esteio (08 de julho de 1978).

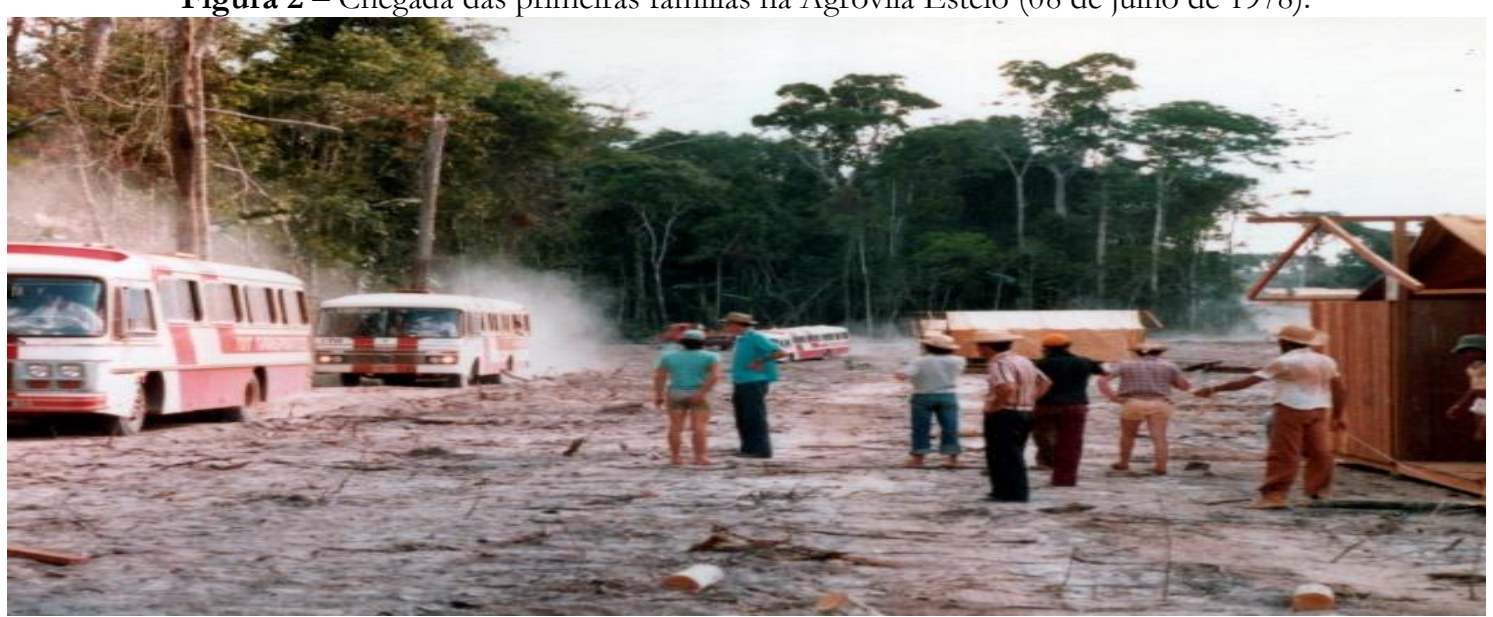

Fonte: Acervo da Secretaria Municipal de Educação, Nova Guarita, MT, 2019.

A instalação das agrovilas ocorreu a dez quilômetros uma da outra. A primeira foi a agrovila Esteio (Figura 3), seguida da Planalto, Nonoai e Guarita, perpendicularmente a então rodovia J-1, hoje MT-208. O nome das agrovilas possui relação com os locais de proveniência dos camponeses. A escolha para a instalação das agrovilas ocorreu apenas pela distância de uma em relação à outra e não pelas características do relevo, do bioma local ou de outros elementos geográficos como rios e córregos. 
|O Projeto de Assentamento Conjunto Terranova I na borda meridional da Amazônia MatoGrossense: efeitos territoriais da ocupação|

|José Aldair Pinheiro | Aumeri Carlos Bampi | Carlos Alberto Franco da Silva |

Figura 3 - Agrovila Esteio - Projeto Terranova I, em meio a floresta Amazônica (1978).

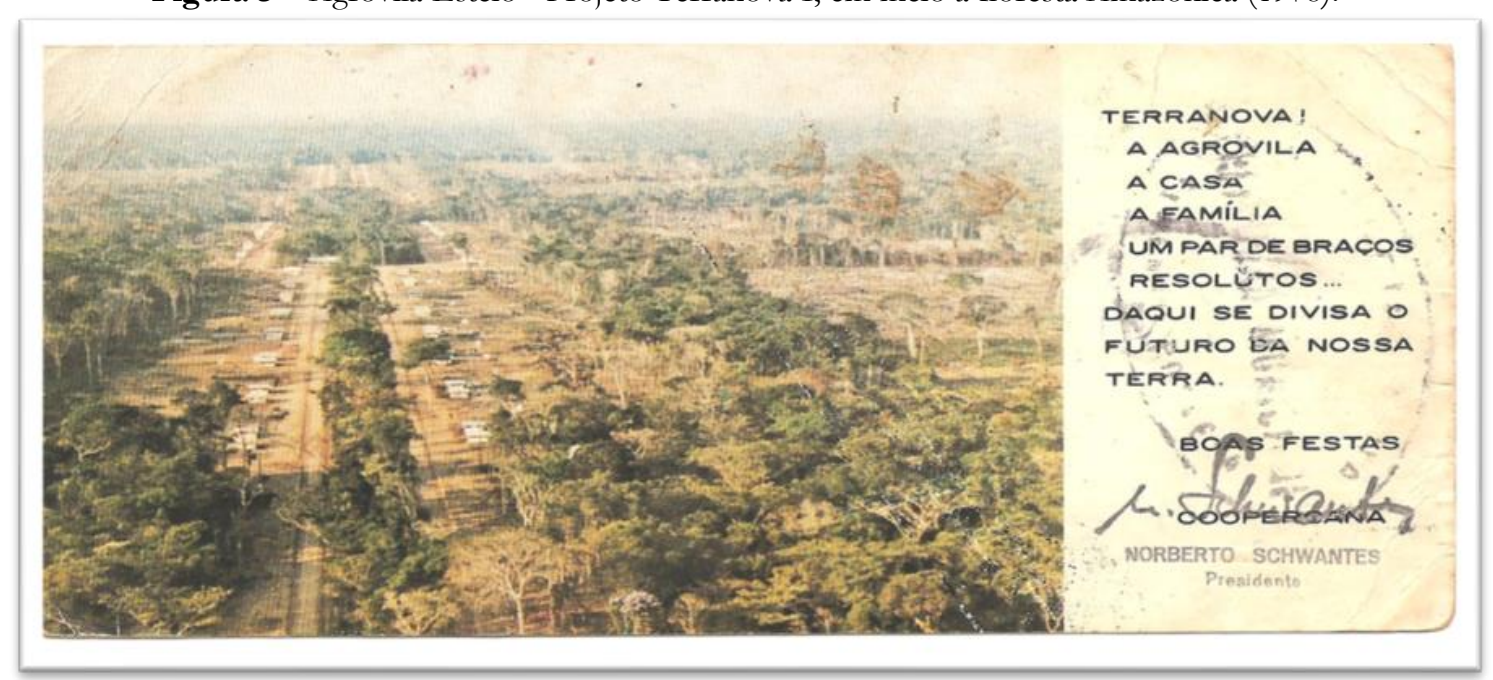

Fonte: Acervo da Secretaria Municipal de Educação, Nova Guarita, MT, 2019.

As agrovilas foram constituídas com espaço residencial, centro administrativo e um espaço social. Previa-se a construção de um centro de convivência, uma escola, campo de futebol e uma igreja de confissão católica. Além da religiosidade, vale ressaltar práticas socioculturais, como encontros festivos, festas de padroeiros, bailes, jogos de futebol, reuniões familiares, rodas de chimarrão, visitas aos vizinhos e auxílios em forma de mutirão. Todas essas ações coletivas tiveram continuidade e replicavam a cultura originária.

De acordo com o projeto do PAC Terranova I, a distribuição dos lotes seguiu a numeração das agrovilas. Cada assentado, denominado pelo INCRA de parceleiro, adquiriu três áreas distintas, sendo: 1- um lote/chácara de $16.000 \mathrm{~m}^{2}$ (dezesseis mil metros quadrados) a $19.000 \mathrm{~m}^{2}$ (dezenove mil metros quadrados) localizado na sede de cada agrovila e destinado à residência e produção da alimentação de subsistência inicial; 2- um lote de 100 ha (cem hectares) destinado ao aproveitamento agrícola; 3- uma parcela ideal correspondente à área agricultável, constituída em condomínio florestal, como forma de abrigar a reserva legal de todo o assentamento. Assim, atendiam-se as normas legais para áreas agrícolas dentro da Amazônia Legal à época, que era de 50\% (Lei no 4.771/65, Institui o Novo Código Florestal no Brasil). O projeto previa ainda uma área de reserva para o núcleo urbano e uma área de reserva técnica para o desenvolvimento de pesquisas agrícolas (CASTRO et al., 2002).

\section{A abertura: a floresta, a fauna, solo e água como recursos a serem apropriados}

Nos registros de Schwantes (1989), a elaboração do PAC Terranova considerou a legislação da época para tratar das questões ambientais; porém, quando da execução da abertura das chácaras e lotes agrícolas, não foi mais possível seguir o planejamento, devido 
|O Projeto de Assentamento Conjunto Terranova I na borda meridional da Amazônia MatoGrossense: efeitos territoriais da ocupação|

|José Aldair Pinheiro | Aumeri Carlos Bampi | Carlos Alberto Franco da Silva |

à urgência em retirar as famílias do Rio Grande do Sul e realizar a sua realocação.

Para a derrubada da floresta, tanto nas áreas das chácaras das agrovilas quanto na dos 100 hectares destinados às atividades agrícolas, foi empregado o uso de potentes tratores de esteira com enormes e pesadas lâminas e correntes (correntões) que seguiram lado a lado, abrindo um traçado na linha demarcatória dos lotes. Neste processo, os córregos e nascentes foram ignorados como recurso fundamental do bioma e a floresta amazônica foi sendo arrancada e amontoada em fileiras de modo a facilitar à queimada.

Os lotes rurais foram recortados seguindo a rodovia e, posteriormente, distribuídos a cada família, em uma extensão de cinco quilômetros a cada lado da agrovila. Desse modo, em todos os lotes, a abertura de áreas de floresta atingiu diretamente as nascentes, mananciais, áreas úmidas e os córregos. Como a abertura não seguiu o planejamento ambiental, a floresta e os recursos hídricos foram afetados drasticamente.

De acordo com os agricultores entrevistados, durante a derrubada da floresta, os tratores-esteiras empurravam a vegetação para dentro dos córregos, rios e áreas alagadas. Não foram respeitadas as áreas de preservação permanente (APPs) nem as nascentes. Os córregos e nascentes se tornaram locais de empilhamento da floresta derrubada, que, em seguida, era queimada de modo a realizar aproveitamento maior das áreas. Os camponeses descapitalizados também utilizaram do trabalho manual com machados, foices e motosserras, materiais distribuídos através da cooperativa, e avançavam sobre a mata realizando a derrubada para posterior queimada, prática que perdurou muitos anos.

Não obstante o bioma da Amazônia causasse admiração e medo por causa de sua imponência e exuberância e fauna desconhecida, para os camponeses, a floresta era percebida como algo a ser desbravado e transformado em espaços produtivos familiares, conforme eles afirmaram nas entrevistas. Em linhas gerais, o camponês estava voltado ao desejo de possuir uma área agrícola, desenvolver a produção e estabelecer um novo espaçotemporalidade. No contínuo processo de transformação da paisagem construído desde a chegada, os elementos naturais tiveram funções essenciais junto às famílias. Além da terra para plantio, a floresta foi utilizada como local de busca de recursos naturais, tais como lenha, madeira e alimentação. Ou seja, para o camponês migrante, o bioma se apresentava tanto como obstáculo quanto possibilidade de reprodução campesina.

A fauna local passou a ser vista como caça e comida. Os espécimes visados eram: Anta (Tapirus terrestris), Veado (Mazama americana e o Ozotoceros bezoarticus), Paca (Cuniculus paca), Caititu (Pecari tajacu), Jacaré-açú (Melanosuchus niger) e Queixada (Tayassu pecari). A fauna também era usada para domesticação de papagaios e araras, situação comum nas casas dos assentados que recolhiam os filhotes quando da derrubada das árvores. 
|O Projeto de Assentamento Conjunto Terranova I na borda meridional da Amazônia MatoGrossense: efeitos territoriais da ocupação|

|José Aldair Pinheiro | Aumeri Carlos Bampi | Carlos Alberto Franco da Silva |

No período inicial, o abastecimento de água para consumo humano nas agrovilas era feito pela COOPERCANA por meio de um caminhão pipa. Em face da problemática do acesso à água potável nas agrovilas, com a perfuração de poços pelas famílias, a cooperativa adquiriu filtros, pois o problema era a característica físico-química da água: de coloração branca e presença de material orgânico em suspensão. Posteriormente, foi realizada a instalação de poços artesianos e rede de distribuição de água. Por fim, a inexistente rede de esgoto adequada nas agrovilas era um problema para a saúde (verminoses e diarreia).

Quando se mudaram para os lotes agrícolas, normalmente para a obtenção da água, as famílias construíram as primeiras moradias próximas aos córregos para facilitar o uso cotidiano, bem como para que os animais domésticos tivessem acesso a esse recurso. $\mathrm{O}$ consumo de água para a criação (aves, suínos e bovinos) utilizou a dessedentação, a partir de poços rudimentares construídos manualmente que serviam para irrigar hortas, pomares e jardins no período da estiagem, entre os meses de maio a agosto/setembro ou mesmo através do acesso direto a nascentes e córregos. A proximidade das habitações rurais com os córregos facilitava a perfuração manual de poços. De fato, era fácil encontrar água com perfuração manual, em forma de cisterna, mas "a duração era pequena porque a borda desmoronava devido ao solo arenoso" (Sr. Paulo, assentado, 65 anos). Com a erosão, os assentados eram obrigados a abandoná-los e a construírem novos poços com mais durabilidade.

De um modo geral, a água das bacias hidrográficas e microbacias na Amazônia mato-grossense era vista como um problema devido à falta de infraestrutura, "pois faltavam pontes, bueiros e interligações” (Sr. Antônio, assentado, 67 anos). Em face do clima, o excesso de chuvas, em determinadas épocas do ano, trazia sérios desafios para os assentados, notadamente pelo desconhecimento ecológico-cultural do bioma e da estação chuvosa amazônica. Apesar dos problemas, os córregos foram utilizados como local de lazer e de sociabilidade em todo o período do ano, situação que no Rio Grande do Sul somente era permitido nos meses do verão. Segundo Schwantes (1989), decerto, isso alterava a identidade gaúcha. "O divertimento era o futebol e o banho de rio", assinala Celso (filho de assentado, 53 anos).

A proximidade dos rios contribuiu para a pesca como fonte de alimentação, dada a diversidade e abundância da ictiofauna na bacia amazônica. Segundo relatam os agricultores, havia muitos córregos com fartura de peixes. As espécies capturadas para consumo eram: Trairão (Hoplias lacerdae), Traíra (Hoplias malabaricus), Pintado (Pseudoplatystoma corruscans), Piranha Preta (Serrasalmus rhombeus), Piau (Leporinus obtusidens), 
|O Projeto de Assentamento Conjunto Terranova I na borda meridional da Amazônia MatoGrossense: efeitos territoriais da ocupação|

|José Aldair Pinheiro | Aumeri Carlos Bampi | Carlos Alberto Franco da Silva |

Lambari (Astyanax), Cachorra (Hydrolycus scomberoides), Jaú (Paulicea lutkenı), Pacú (Piaractus brachypomus), Cachara (Pseudoplatystoma fasciatum), Matrinxã (Brycon cephalus), Bicuda (Boulengerella), dentre outras.

Os assentados aprenderam a converter a caça e pesca em alimentação para sobrevivência, sobretudo no início. As enormes distâncias aos mercados e a pobreza dos assentados dificultaram o acesso aos alimentos e mantimentos. A agricultora aposentada (Sra. Madalena, 80 anos) sinaliza que, no contexto de precariedade e falta de alimentação, num momento de desespero e raiva no período inicial, ela jogou todas as panelas para fora da casa, dada a situação de carestia e dificuldade alimentar. A desesperadora situação, que era coletiva, abria espaço para a exploração dos recursos da floresta. O problema era que, tanto a caça como a pesca tornaram-se contínuas e sem o cuidado à reprodução das espécies animais.

\footnotetext{
(...) a caça e a pesca, nos primeiros anos ajudou na alimentação, mas depois se tornou um vício para muitos porque todos dias iam caçar. Também havia gente que fazia coleção de peles de bichos. Iam nos rios da região e pescavam até que podiam carregar. (...) boa parte dos peixes estragavam, não eram aproveitados porque não tinham como guardar uma vez que não havia energia elétrica para refrigeração (Sr. José, filho de assentado, professor, 48 anos, fevereiro de 2017).

Dava dó ver tantos bichos mortos. Porque na verdade não aproveitavam todos (...) por isso que hoje sumiram os animais e já não têm peixes (Sr. Domingos, assentado, 65 anos, abril de 2018).
}

A situação mostra um uso sem o devido conhecimento ecológico dos recursos naturais disponíveis, prática realizada anteriormente nas áreas do bioma da Mata Atlântica, de onde eram provenientes. Evidencia-se ainda a falta de assistência governamental e suporte material a uma população altamente vulnerável em termos socioeconômicos.

\section{Os desafios da agricultura familiar e sua suplantação pela pecuária bovina}

Desde o início, com a chegada das famílias, o sonho da agricultura na nova terra mostrou-se difícil, com uma série de obstáculos e problemas de ordem estrutural e ambiental. A organização prometida não atendeu às necessidades e a falta de conhecimentos acerca do clima e ecossistema local levou parte das famílias a abandonar as terras, retornando ao Rio Grande do Sul ou buscando novas áreas. O desenvolvimento da agricultura foi um enorme desafio para os camponeses e para a cooperativa, pois ignoravam as características do clima, do bioma e do solo, e sequer havia estudos sobre o desenvolvimento agrícola referentes à região.

Assim que começaram os plantios de hortaliças, pomares, cultivo de arroz, feijão e 
|O Projeto de Assentamento Conjunto Terranova I na borda meridional da Amazônia Mato-

Grossense: efeitos territoriais da ocupação|

|José Aldair Pinheiro | Aumeri Carlos Bampi | Carlos Alberto Franco da Silva |

milho surgiram os problemas da produção e, consequentemente, houve por parte dos agricultores a exigência de assistência técnica. Entretanto, os técnicos da cooperativa eram formados numa realidade agronômica de solo e clima do Sul do Brasil. Os conhecimentos agrícolas disponíveis eram incompatíveis e, postos em prática, não davam resultados satisfatórios, o que gerou uma situação conflituosa com a cooperativa.

\footnotetext{
Nas reuniões da cooperativa os técnicos agrícolas falavam que aqui era um período de seca e outro de chuva. Mas a gente não imaginava que era tanto. Chovia a semana inteira, o mês inteiro, nem via o sol. A produção de arroz e feijão apodrecia na roça. Muitos lugares virava um lamaçal e não dava para entrar nem com a carroça e os bois. Os córregos destruíam as pontes (Sr. Eugênio, assentado, 66 anos).

A cooperativa incentivava o plantio do café, guaraná, seringueira, porque estava no projeto, mas ninguém conhecia isso, nem os técnicos. O problema era: - Do que o povo iria viver até as plantas produzirem? (Sra. Ana, assentada e professora, 72 anos).

Aqui ninguém conhecia nada. Tivemos que aprender a lidar com a terra, aprender sobre o clima, as plantas, as chuvas, a seca... Foi complicado (Sr. João, assentado, 66 anos).
}

Conforme Castro et al. (2002, p. 75), na avaliação da COOPERCANA e da Comissão Especial que veio do Rio Grande do Sul, em 1981, para verificar in loco a situação dos colonos, o motivo da saída do projeto ocorreu devido à falta de capacitação para o exercício da profissão de agricultor autônomo em regime de economia empresarial.

No entanto, há outros de elementos a considerar: 1) parte das famílias que se deslocaram ao norte mato-grossense havia diminuído a relação com a agricultura, pois estavam em periferias de cidades; 2) houve problemas graves de saúde no assentamento, com intensos surtos de malária; 3) havia muitos problemas financeiros entre os agricultores empobrecidos e descapitalizados e não houve suporte governamental; 4) a escolarização era baixa e dificultava o entendimento do mecanismo de financiamento bancário que se propunha na modernização agrícola brasileira e mesmo o domínio de novas técnicas; 5) a subordinação do assentado à cooperativa e ao Estado dificultava a busca por apoio político e técnico para superar a situação; 6) e, por fim, tanto os técnicos quanto os camponeses levariam um tempo considerável a entender o clima, o solo e a dinâmica do bioma Amazônia.

Dessa forma, o assentamento passou por momentos dramáticos ao longo dos primeiros anos. Com mudanças políticas no governo federal e a crise fiscal do Estado brasileiro no final da década de 1970, o apoio financeiro se esvaiu. Assim, o projeto ficou a cargo apenas da cooperativa, que, sem recursos e com parca produção agrícola, entrou em colapso e ficou sem condições de suporte aos assentados, que se viram à própria sorte.

Portanto, a desistência de muitos assentados tem mais a ver com a ausência e 
|O Projeto de Assentamento Conjunto Terranova I na borda meridional da Amazônia MatoGrossense: efeitos territoriais da ocupação|

|José Aldair Pinheiro | Aumeri Carlos Bampi | Carlos Alberto Franco da Silva |

ineficiência das políticas públicas do que simplesmente com a falta de capacitação empresarial. A causa do fracasso de muitos agricultores tem a ver com uma política descomprometida com os reais interesses dos trabalhadores rurais que se encontravam fragilizados na região de origem e foram abandonados no assentamento em região desconhecida e adversa, sem um mínimo de suporte do Estado.

Coube aos assentados buscar solução própria aos desafios na nova terra, utilizandose, sobremaneira, de modo insustentável dos recursos naturais disponíveis para a alimentação e subsistência, bem como para o desenvolvimento das atividades econômicas. Além dos parcos recursos oriundos da agricultura familiar, realizavam a venda de madeira.

O aprendizado e a construção de saberes ocorreram através da troca de experiências, sendo que a vida comunitária contribuiu para a socialização, debate e superação de parte dos problemas vividos, ao mesmo tempo em que se intensificava um processo empírico do uso e ocupação do solo com alta degradação ambiental.

A população de agricultores deslocada para a Amazônia mato-grossense não recebeu orientações sobre a dinâmica e a interação com a natureza, nem mesmo frente à atividade de produção a ser empregada na região. A questão primeira, que era fortalecida nos discursos do INCRA e COOPERCANA, era a necessidade de abertura de áreas. Diante de uma nova realidade, entretanto, a forma de ocupação adotada e a maneira de usar o solo em uma localidade, aquilo que dizia ser moderno e atualizado, promissor e estimulante, apresentavam-se como um erro de perspectiva (RESENDE et al., 2002).

Aos poucos reproduziu-se a problemática social vivida no Rio Grande do Sul: descaso das políticas públicas para com os agricultores, concentração de terra, conflitos e violência, expropriação dos recursos naturais e exploração de mão de obra.

As comunidades de migrantes provocaram mudanças socioambientais na Amazônia, vivenciaram-nas e participaram ativamente das profundas transformações socioespaciais, culturais e ambientais desde o início da colonização, em 1978, até a presente década. Essencialmente, na condição em que se encontrava, o que importava ao assentado era o acesso à terra, pois significava conquista social, mas logo notaria que isto não era suficiente. Para o campesinato, ser proprietário de terra, significava a possibilidade de uma produção própria de alimentos e venda do excedente, mesmo em circunstâncias difíceis. Em suma, a despeito dos problemas de permanência no assentamento por causa das condições edafoclimáticas e da dificuldade de acesso ao crédito, à tecnologia e à logística de distribuição da produção, muitos colonos resistiram às adversidades a fim de fixarem a terra como uma forma de r-existência campesina, assinalam Faria et al. (2015, p. 359).

A narrativa da panaceia da modernização era parte do imaginário coletivo 
|O Projeto de Assentamento Conjunto Terranova I na borda meridional da Amazônia MatoGrossense: efeitos territoriais da ocupação|

|José Aldair Pinheiro | Aumeri Carlos Bampi | Carlos Alberto Franco da Silva |

positivista dos assentados sulistas em seu crédito no trabalho, progresso e emancipação econômica. Assim, a colonização envolvia uma fala-discurso dos entrevistados: "abrir a mata era trazer o progresso"; era "domar" a natureza para a criação de espaços permanentes de agricultura e pecuária para fins de melhoria econômica das famílias. De acordo com depoimento de um dos assentados, "ninguém tratava ou se importava com questões ambientais, nem o governo. Importava sobreviver, produzir, sair da pobreza”. E acrescenta: "muito menor era a preocupação com floresta, ou com água, pois a gente pensava na produção. A natureza, a floresta, a água nunca iriam acabar. Existia em abundância" (Sr. Nilson, assentado, 73 anos).

Neste aspecto é preciso considerar que no Brasil ainda ecoava o discurso nacionaldesenvolvimentista. Tanto para o Estado quanto para a sociedade brasileira, não estava em pauta a temática ambiental. Somente a partir da década de 1990, o tema do desenvolvimento ambientalmente sustentável passou a fazer parte das políticas públicas e ganhou maior visibilidade, sobretudo após a Eco-92, realizada na cidade do Rio de Janeiro.

Nesse processo, a questão do desmatamento intenso e a forma de ocupação e uso do solo foram decisivas para que, dentro do processo de adulteração intensa do bioma da Amazônia na área ocupada pelo projeto, fossem criadas condições de intensa perda da biodiversidade e alta vulnerabilidade hídrica.

O uso e a ocupação do solo, tendo por base o desflorestamento raso, em primeiro momento para a agricultura e especificamente para a pecuária extensiva, que se instalou a partir da década de 1990, em decorrência da influência da presença de latifúndios pecuaristas no entorno do projeto, constituíram a tônica. Assim, sem que houvesse um processo de proteção de nascentes, mananciais, córregos e rios, enfim, das áreas úmidas do bioma, se desenvolveu a abertura e implantação das atividades econômicas. As bacias e microbacias foram tratadas como empecilho no decurso da ocupação do solo.

No momento da abertura, o determinante era a expansão da extensão (área) de terra utilizável, sem que a gestão dos recursos florestais e hídricos assumisse relevância. Pelo menos até o momento em que, dadas as consequências da devastação, a problemática da água passou a ser sentida por conta de a escassez implicar na atividade produtiva.

Assim, a escassez da água acabou gerando complicadores ao próprio modelo de desenvolvimento adotado, pois as nascentes, córregos, riachos e rios que já haviam sido impactados pela extinção das APPs começaram a secar e ter o fluxo interrompido todos os anos no período anual da estiagem, em especial a partir da década de 2000, constituindo comprometimento à pecuária leiteira e de corte, base econômica da comunidade.

Outro elemento a considerar para a degradação é que a pecuária, além de produzir 
|O Projeto de Assentamento Conjunto Terranova I na borda meridional da Amazônia MatoGrossense: efeitos territoriais da ocupação|

|José Aldair Pinheiro | Aumeri Carlos Bampi | Carlos Alberto Franco da Silva |

compactação do solo, dava acesso direto do rebanho aos canais hídricos, e isso provocava contínuo assoreamento. Tal situação ocorreu numa replicação da situação vista nos latifúndios do entorno, conforme relatos dos assentados, e continua na atualidade, situação comprovada pelas visitas junto às propriedades.

Dessa forma, em linhas gerais, a questão ambiental do projeto está relacionada a vários problemas. A percepção dos colonos era a de que seria necessário derrubar totalmente a mata nos lotes rurais para trabalhar a agricultura de arroz, feijão, milho. O Código Florestal (Lei no 4771, de 15 de setembro de 1965 - Governo Federal do Brasil), hoje revogado, no artigo 44 estabelecia, no entanto, que qualquer propriedade na Amazônia Legal devia preservar o mínimo de 50\% da cobertura arbórea; por isso o projeto previa e foram criados blocos de reservas florestais coletivas, seguindo o modelo de colonização alemã na região da Floresta Negra (SOARES FILHO, 1998). A área de reserva ambiental, denominada de Quatro Reservas (86.354 ha - oitenta e seis mil trezentos e cinquenta e quatro hectares), equivalente aos lotes, foi demarcada em uma região próxima à área do assentamento.

A partir de meados da década de 1980, no entanto, poucos anos depois do início do assentamento, as áreas destinadas à reserva legal foram invadidas por posseiros, grileiros de terras e grandes fazendeiros, gerando tensão social em virtude da exploração ilegal da madeira e intensa mineração do ouro. Posteriormente, foi realizada uma divisão informal, ilegal e irregular dos lotes e realizada a ocupação para agricultura e pecuária, constituindo-se em razão de intenso conflito fundiário e ambiental, que permanece insolúvel. Segundo Castro et al. (2002), em 1988, na reserva florestal do projeto existiam onze comunidades de posseiros, num total de duas mil famílias, número bem maior que as famílias assentadas em todo o Projeto Terranova I e II que foi, aproximadamente, mil e duzentas famílias.

Os agricultores que tiveram as reservas legais condominiais invadidas (áreas de reserva legal) se sentiram prejudicados, mas pouco puderam fazer diante da conivência do poder público e da participação de autoridades de altas esferas na retirada e comercialização ilegal de madeiras, bem como de exploração de áreas ilegais de garimpo e mesmo comercialização ilegal de terras de suas áreas de reserva florestal legal. Além disso, temiam a violência da pistolagem, muito comum na região.

Diante do histórico conflito fundiário instalado na área denominada Quatro Reservas, tanto posseiros como os parceleiros proprietários têm suscitado do poder público solução para o problema através de audiências públicas e recursos legais como é o caso da Lei Estadual n 8.680/2007, que autorizava o estado de Mato Grosso a permutar a área concernente às Quatro Reservas com outra área de mesma extensão no município de 
|O Projeto de Assentamento Conjunto Terranova I na borda meridional da Amazônia MatoGrossense: efeitos territoriais da ocupação|

|José Aldair Pinheiro | Aumeri Carlos Bampi | Carlos Alberto Franco da Silva |

Colniza, MT. Porém, em 2013, foi julgada a inconstitucionalidade da lei por se contrapor com o disposto nos artigos 23 e 225 da Constituição Federal, e artigos. 263 e 274 da Constituição Estadual. Desde então, não houve avanço na resolução do problema e a área de reserva legal encontra-se em uso por atividades de agricultura, pecuária e garimpos.

No aspecto político/econômico, dentro do assentamento Terranova I, em conformidade com a política agrícola que se projetava sobre o país, os colonos foram conclamados a "dominar" a floresta e a promoverem a fala-discurso do desenvolvimento. "Gente que deixava mata era atrasado, preguiçoso", como expõe uma professora aposentada (Maria, assentada, 72 anos). Na chegada às agrovilas, relatam os assentados em suas memórias que ficaram impactados com a imensidão e altura da floresta amazônica. Por conseguinte, as clareiras derrubadas com o uso de tratores e enormes correntes, viabilizadas pela cooperativa, simbolizavam a chegada do desenvolvimento, espaço para o exercício do trabalho camponês.

Questões sanitárias também influenciaram o processo de desmatamento. Schwantes (1989) expõe que, na elaboração do projeto do assentamento com pequenos núcleos urbanos, as agrovilas serviram para evitar a dispersão e isolamento das famílias na mata e eventuais problemas com a malária e febre amarela. A doença já era um problema conhecido na Amazônia. No PAC Terranova, após dois anos da chegada das famílias, foi registrado grande surto da doença. No intuito de contribuir com a prevenção de casos, a população entendeu, a partir das informações dadas por técnicos da SUCAM (Superintendência de Campanhas de Saúde Pública), que a derrubada da mata, ou limpeza como denominavam, nas proximidades das nascentes, córregos e riachos evitaria a formação, reprodução e disseminação de focos da malária.

\section{Dinâmica de uso e ocupação}

No tocante ao desenvolvimento do assentamento, a área originária destinada a uso agrícola utilizava os seguintes procedimentos: 1- abertura de clareiras para uma espécie de base; 2- derrubada da floresta; 3 - atear fogo para o que denominavam de limpeza da área; e finalmente 4- o plantio de arroz, feijão e milho e, em período posterior, as pastagens.

Neste contexto, as comunidades passaram a conviver anualmente com o desmatamento, os incêndios e queimadas das matas. Na década de 1980, a ocupação do solo era destinada a pequenos cultivos agrícolas de arroz, milho e feijão. Houve também a inserção de atividades de plantio de pastagens à pecuária bovina, e o processo de supressão da floresta originária se intensificou, em especial na década de 1990, chegando à década de 2000 praticamente em sua totalidade (Figura 4). 
|O Projeto de Assentamento Conjunto Terranova I na borda meridional da Amazônia MatoGrossense: efeitos territoriais da ocupação|

\section{|José Aldair Pinheiro | Aumeri Carlos Bampi | Carlos Alberto Franco da Silva |}

No que se refere à atividade da pecuária bovina, muitos colonos relatam que a inserção de sementes de gramíneas para o desenvolvimento da pecuária demandava a queimada de áreas de floresta para semeadura de Capim Brizantha (Urochloa brizantha). Para tanto, aproveitavam-se da condição climática da estiagem anual. Além disso, a floresta possuía alto grau de combustão devido ao acúmulo de serapilheira e diminuição da umidade. Tal situação se tornou comum e foi realizada, sequencialmente, ano a ano nos lotes rurais. Tal prática estava fundada no modelo expansionista e extensivo da produção pecuária que já era desenvolvido na Amazônia, em especial em grandes propriedades. $\mathrm{O}$ objetivo era aumentar o tamanho da área e assim avançava também sobre a APP.

[...] para quem não tinha dinheiro para pagar trator, a solução era abrir aos poucos, derrubando e colocando fogo. Boa parte dos pastos foi formada assim: o fogo passava e era jogada a semente de capim brizantha na cinza, igual às fazendas. A cada ano aumentava um pouco. Era fácil para roçar, porque nas áreas com mata mais alta precisava derrubar. Os carreadores dos madeireiros facilitavam adentrar para espalhar o capim (Sr. Odair, assentado, 65 anos).

Figura 4 - Mapa da dinâmica de uso e ocupação do solo

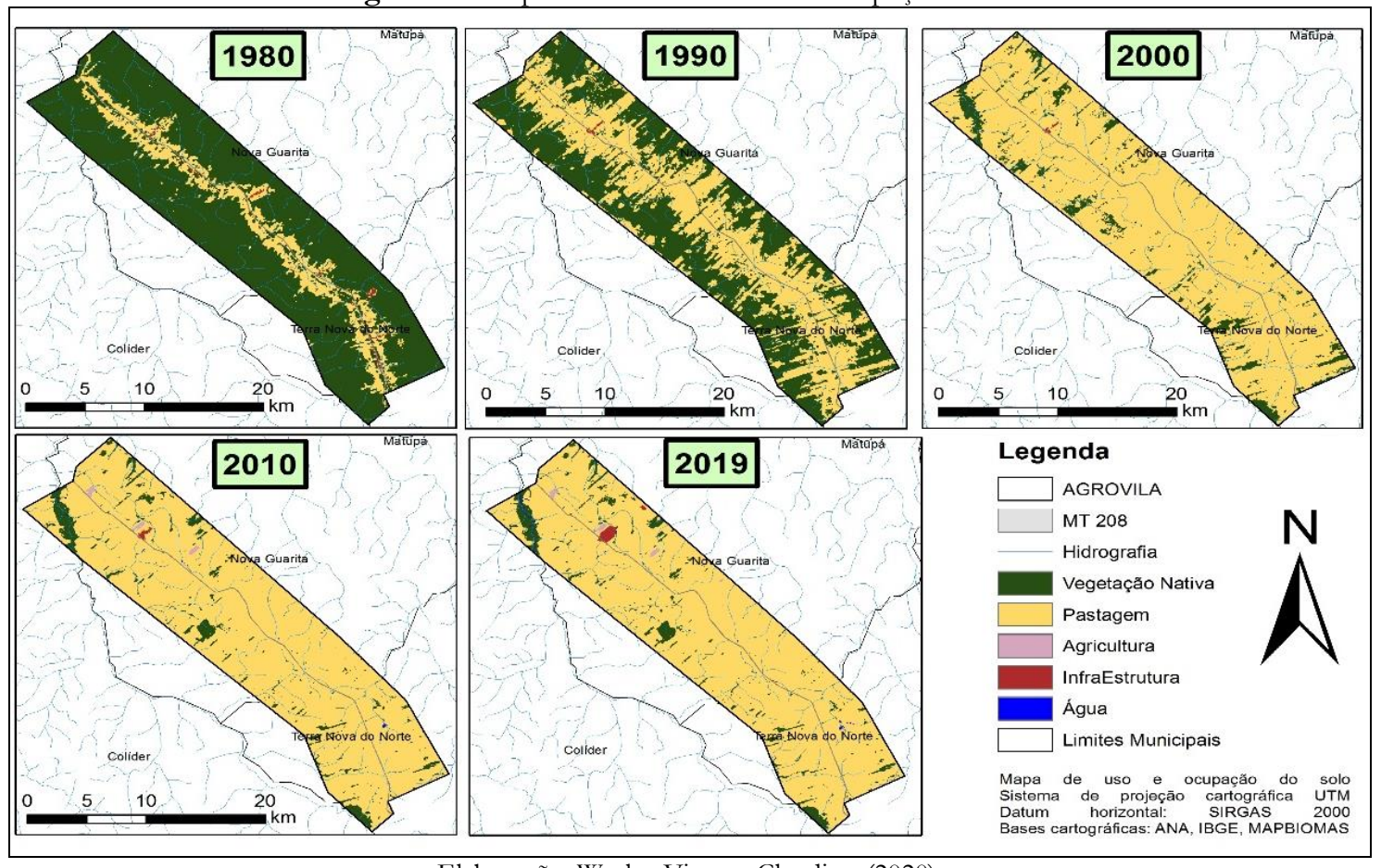

Elaboração: Wesley Vicente Claudino (2020).

Neste sentido, conforme a figura 4, observa-se intenso desflorestamento na área agrícola no período de duas décadas, para fins, sobretudo, de expansão das pastagens. Houve radical alteração da cobertura original do solo e à dinâmica hídrica, com alto impacto ambiental. Pelo fato de possuir reserva legal condominial separada da área de cultivo e alegando seguir razões sanitárias, as matas das margens dos córregos e dos rios 
|O Projeto de Assentamento Conjunto Terranova I na borda meridional da Amazônia Mato-

Grossense: efeitos territoriais da ocupação|

|José Aldair Pinheiro | Aumeri Carlos Bampi | Carlos Alberto Franco da Silva |

também foram suprimidas, pois, segundo relatavam, serviam para proliferação da malária e febre amarela.

Tanto no período inicial quanto posterior, a malária aparece como um dos maiores desafios no imaginário coletivo; pouco sabia sobre a doença antes do assentamento. Sabiase que estava associada à água e às matas. Desse modo, a preocupação era como controlar a epidemia da doença. Uma alternativa foi a dedetização das residências e áreas próximas às habitações. Um assentado (Sr. Valter, 65 anos) relata que "as paredes da casa ficavam brancas de veneno e era proibido lavar". Ele sinaliza ainda que os técnicos da Superintendência de Campanhas de Saúde Pública (SUCAM) faziam pulverização com inseticidas e forneciam orientação para a limpeza das áreas úmidas onde os mosquitos se reproduziam: "O pessoal da SUCAM sempre falava para a gente ter cuidado com o mato na beira da sanga [córregos], porque ali eles [os mosquitos] se reproduziam. Eu mesmo derrubei tudo, até nas ressacas da grota, assim como os outros fizeram" (Sr. Paulo, assentado, 68 anos).

As práticas de relação desenvolvidas com o bioma contribuíram consideravelmente para a construção de forte vulnerabilidade ambiental, sobretudo a vulnerabilidade hídrica. Matas ciliares dos córregos e nascentes foram totalmente derrubadas e ardiam todos os anos, para fins de inserção de gramíneas forrageiras destinadas à pastagem extensiva do gado. Assim, é possível, na atualidade, estabelecer uma relação direta entre o desflorestamento, as queimadas, a perda da biodiversidade, a destruição das matas ciliares e a questão da escassez da água, uma vez que os leitos de córregos sofreram com a derrubada, com as constantes queimadas e com o assoreamento provocado pelo acesso direto do gado para dessedentação.

Outro vetor facilitador para a derrubada e degradação da floresta foi as estradas denominadas de carreadores, construídas pelos madeireiros para exploração florestal e que permitiam o acesso para a derrubada e produção de queimadas para inserção de sementes de pastagens. Em relação às queimadas, Schwantes (1988, p. 182) relata a necessidade de limpar a área.

\footnotetext{
Pouco antes das primeiras chuvas, no final de agosto (1978), combinamos o dia da grande queimada. Avisamos a todos que aguardassem, cada um na testada do seu lote, o sinal do sobrevoo do avião. No momento em que o avião passasse baixinho, poderiam atear fogo. [...] a fumaça começou a tapar tudo. As labaredas atingiam 30 metros de altura, porque chegavam a queimar a copa das castanheiras que não haviam sido derrubadas. [...] Era aterrorizante a violência do fogo na selva. [...] Foi uma destruição absurda.
}

Além das queimadas nos lotes rurais, muitos colonos atearam fogo nas leiras das 
|O Projeto de Assentamento Conjunto Terranova I na borda meridional da Amazônia MatoGrossense: efeitos territoriais da ocupação|

|José Aldair Pinheiro | Aumeri Carlos Bampi | Carlos Alberto Franco da Silva |

chácaras localizadas nas agrovilas com a finalidade de construir instalações e benfeitorias e novos locais para criação de animais domésticos, além da confecção de hortas e pomares (plantio de hortaliças e árvores frutíferas) destinados à produção alimentar de subsistência.

O fenômeno da queimada programada na área do assentamento contribuiu para o aumento da fumaça e do calor e incidência de incêndio na área do assentamento (SCHWANTES, 1988) e trouxe muitos problemas respiratórios, assim como enorme mortandade de peixes por conta do aquecimento das águas dos riachos e das cinzas, que eram recolhidos para alimentação. A situação causou danos irreversíveis à ictiofauna pelo aumento da temperatura e pela deposição de matéria carbonizada nos riachos e nas matas ciliares. De acordo com Pinheiro (2009), a alta taxa de desmatamento no município de Nova Guarita e Terra Nova está relacionada a tais práticas.

Foi na década de 1980 que ocorreu a intensificação da derrubada das florestas sendo agravada na década de 1990, substituídas por áreas de pastagens, uma vez que sentiram as dificuldades para a agricultura familiar. No contexto, a atividade da pecuária bovina constituía uma possibilidade de renda à dramática situação econômica. Conforme cita um agricultor aposentado, "a pequena agricultura não tinha mais condição, não dava futuro. Quase todo mundo abandonou e foi para o garimpo buscar trabalho, ter um pouco de renda. Com o recurso do garimpo comprava o gado" (Sr. Arno, assentado, 70 anos).

A descoberta de ouro na região aconteceu no início da década de 1980 nos municípios de Alta Floresta, Matupá e Peixoto de Azevedo, na bacia hidrográfica do Rio Teles Pires e microbacia do Rio Peixoto de Azevedo, em locais próximos ao assentamento. Como o minério era encontrado na forma aluviar com pouca profundidade, necessitava de baixo investimento para a extração. Com estrutura manual e uso rudimentar de motores, os garimpos fizeram uso de mão de obra inicial de contingentes oriundos das regiões Nordeste e Norte. Entretanto, no contexto das dificuldades da agricultura camponesa e ausência de renda no assentamento, grande parte da mão de obra masculina ingressou na atividade garimpeira. Seus sítios ficaram a encargo precário das mulheres e crianças.

A atividade nos garimpos era realizada em condições laborais insalubres com relações trabalhistas precárias ou inexistentes. Relatam os camponeses que o processo de exploração do ouro era ilegal e em desconformidade com a legislação ambiental. Os rejeitos de mineração eram lançados diretamente nos cursos d'água; no tratamento do ouro empregavam-se metais pesados como o mercúrio ( $\mathrm{Hg}$ - popularmente conhecido como azougue), que era utilizado sem nenhum cuidado com a saúde humana e com o ambiente. Muitos ficavam doentes com malária e mesmo por exaustão física na intensa jornada. No 
|O Projeto de Assentamento Conjunto Terranova I na borda meridional da Amazônia MatoGrossense: efeitos territoriais da ocupação|

|José Aldair Pinheiro | Aumeri Carlos Bampi | Carlos Alberto Franco da Silva |

entanto, eles conseguiam certas quantias para investir na pecuária bovina, que exigia menos mão de obra e foram aplicando os recursos para expansão da pastagem no assentamento.

A atividade garimpeira, embora tenha acontecido no entorno das comunidades do assentamento, causou alto impacto, perdurando até início da década de 1990. No aspecto social houve a incidência da violência e criminalidade, trazendo mudanças consideráveis à rural vida pacata e isolada em meio à floresta Amazônica.

\section{As consequências ambientais da implantação das atividades produtivas}

Podemos afirmar que, além da perda da biodiversidade, extinção da fauna e destruição da APP, a questão hídrica atualmente se constitui um problema relevante à manutenção das comunidades. Os camponeses relatam alterações nos períodos de estiagem e de chuvas, mudança na precipitação e intensificação da escassez de água no período da estiagem, o que resulta em problemas de abastecimento para dessedentação do rebanho.

Quando questionados sobre as causas dessas mudanças as respostas são coincidentes em relação a ser consequência da degradação e o desmatamento que proporcionaram. O histórico do uso e ocupação evidencia o impacto sobre os recursos florestais, hídricos e solo de um modo de ocupação preconizado equivocadamente pelas políticas federais para as áreas de fronteira agrícola na Amazônia. Nota-se a forma como os camponeses desenvolveram as atividades impulsionados pelo discurso da abertura da fronteira e reproduziram a primeira fase da modernização agrícola que inseria tratores, motosserras e fogo, ávidos para ter áreas produtivas e em consequência fazer parte da agricultura comercial, ter renda e viver melhor.

No entanto, já em meados da década de 1980, com a queda nos preços dos produtos agrícolas, a atividade da agricultura familiar foi abandonada, concomitantemente à busca de trabalho na atividade garimpeira do entorno. A expansão das áreas foi destinada à pecuária bovina, que é local e regionalmente a atividade predominante.

A partir das práticas de uso e ocupação da terra, ocorrem impactos imediatos nas microbacias, atingindo principalmente as matas ciliares e sequencialmente se desenvolvem processos erosivos. Verifica-se na área de estudo a retirada total da Área de Preservação Permanente (APP) (Figura 5) para atividades da pecuária que comprometeram os recursos hídricos e a biodiversidade local. 
|O Projeto de Assentamento Conjunto Terranova I na borda meridional da Amazônia MatoGrossense: efeitos territoriais da ocupação|

|José Aldair Pinheiro | Aumeri Carlos Bampi | Carlos Alberto Franco da Silva |

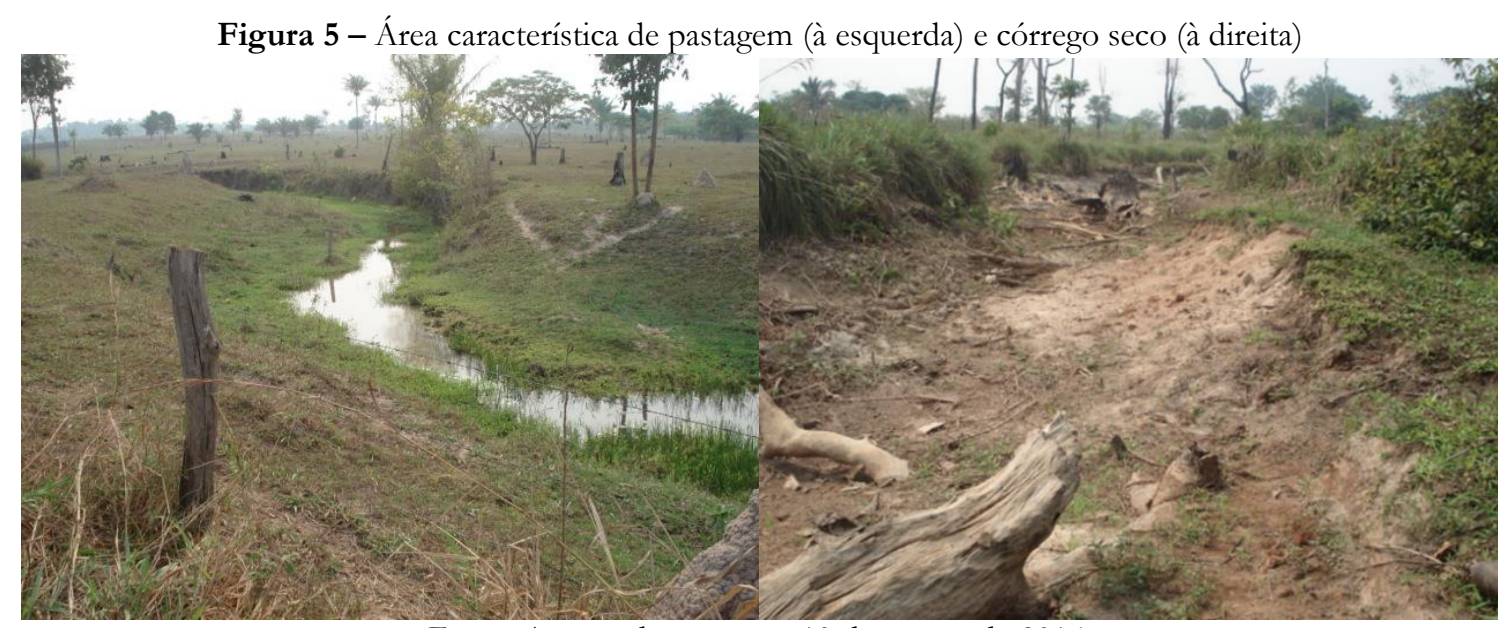

Fonte: Acervo dos autores, 10 de agosto de 2016.

Segundo dados do Projeto de Estimativa do Desflorestamento da Amazônia (PRODES, 2018), Nova Guarita acumula uma área desmatada 86,38\% e Terra Nova do Norte apresenta o desmatamento acumulado de $84,46 \%$. No processo da inserção da modernização produtiva na Amazônia, a paisagem natural foi modificada. No aspecto hídrico, na área do assentamento, a escassez da água, em especial no período de estiagem, impactou fortemente as atividades pecuárias. Diante da problemática crescente, nas duas últimas décadas, os camponeses desenvolveram práticas de mitigação da escassez de água para dessedentação do gado que por vezes são ainda mais complicadoras. Uma delas consiste em construir represamento por meio da interrupção de córregos para formar reservatórios de água destinados à dessedentação do gado na estiagem, situação que resolve em parte o abastecimento, mas acaba por dar amplitude à degradação.

Outra prática que vem aumentando nos últimos anos é a abertura de valas nos leitos secos e assoreados dos córregos (Figura 6). Também são feitas escavações nos leitos ou em áreas úmidas (nascentes assoreadas), o que resulta em poças de água com baixa potabilidade ao rebanho bovino. Essas práticas contam com o apoio da prefeitura municipal de Nova Guarita, MT, que para realizar os serviços utiliza retroescavadeiras, afetando ainda mais os cursos d'água. 
|O Projeto de Assentamento Conjunto Terranova I na borda meridional da Amazônia MatoGrossense: efeitos territoriais da ocupação|

|José Aldair Pinheiro | Aumeri Carlos Bampi | Carlos Alberto Franco da Silva |

Figura 6 - Escavações (à esquerda em área de nascente e à direita em leito de córrego)

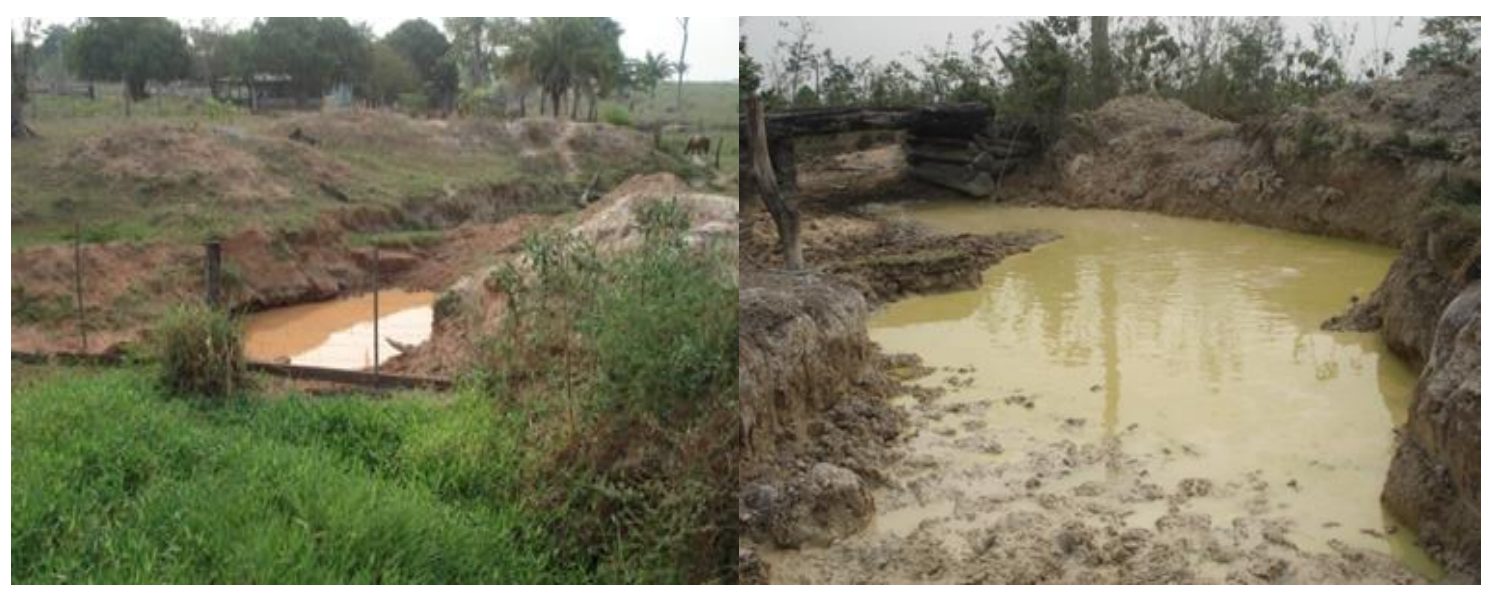

Fonte: Acervo dos autores, 15 de agosto de 2016.

Houve ainda ação do poder público local para enfrentar a escassez no meio rural através da busca de recursos junto ao governo federal, destinados à construção de poços artesianos que foram perfurados em algumas comunidades rurais. Entretanto, os custos desses investimentos foram altos e pelos relatos não atenderam às necessidades, pois a manutenção representava um custo econômico que não é viável aos produtores.

Muitos camponeses têm iniciado voluntariamente a recuperação de áreas degradadas (matas ciliares e nascentes), mas enfrentam dificuldades financeiras e técnicas. Além disso, as políticas públicas ambientais de preservação e conservação dos recursos não se refletem na prática cotidiana da vida camponesa, pois ainda são desconhecidas, de modo que não inibem e nem alteram o modo como se desenvolvem as atividades agrícolas e pecuárias no assentamento, que continuam aumentando o passivo ambiental.

\section{CONSIDERAÇÕES FINAIS}

No âmbito do processo geopolítico de abertura da fronteira, para fins de integração físico e econômica do território brasileiro, o Mato Grosso adquiriu posição estratégia na conquista do heartland sul-americano e de consolidação da divisão inter-regional do trabalbo no país e internacionalmente. Assim, a colonização se afirmava como uma das principais diretrizes de ocupação produtiva em direção à Amazônia. Todavia, no quesito ampliação da margem camponesa e fixação do pequeno produtor migrante à terra, os projetos de colonização resultaram em imensos passivos socioambientais e conflitos fundiários.

A população de agricultores deslocada para a Amazônia mato-grossense não recebeu suficientes orientações sobre a dinâmica e a interação com a natureza, nem mesmo frente à atividade de produção agrícola a ser empregada na região. Tal situação ocorreu tanto por parte do governo federal quanto por parte da Cooperativa, até porque os 
|O Projeto de Assentamento Conjunto Terranova I na borda meridional da Amazônia MatoGrossense: efeitos territoriais da ocupação|

|José Aldair Pinheiro | Aumeri Carlos Bampi | Carlos Alberto Franco da Silva |

agricultores desconheciam o bioma. O INCRA e COOPERCANA, na reprodução discursiva, influíram no desmatamento com a finalidade de produção a qualquer custo.

O desmatamento e a forma de uso e ocupação do solo foram decisivos para que, dentro na adulteração do bioma na área ocupada, fossem criadas condições de perda da biodiversidade com a derrubada da floresta, degradação do solo e escassez hídrica.

Passadas quatro décadas do início, com grande transformação produzida e enorme ônus ambiental, os camponeses remanescentes percebem a insustentabilidade das práticas produtivas. E como num movimento cíclico recaem sobre si as consequências e as cobranças das novas legislações no tocante à recuperação e preservação dos recursos naturais. Se, de um lado, se veem obrigados pela lei, por outro têm necessidades básicas da produção da própria existência. Ainda se sentem abandonados pelas políticas públicas, já que exigências ambientais requerem investimento financeiro e conhecimentos técnicos à recuperação.

Os conhecimentos técnicos encontram obstáculos na sucessão familiar, pois os herdeiros não se sentem encorajados ao desafio e trabalho, além disso, muitos desses filhos laboram em outras cidades da região, uma vez que a atividade nas propriedades não é rentável à manutenção das famílias ampliadas. Assim, a problemática vai se postergando.

Observamos que o PAC Terranova foi marcado pela busca de crescimento material, com objetivos imediatos e influenciado pelos determinantes do mercado nacional e internacional e da doutrina de segurança nacional que moveu populações camponesas sem mexer na estrutura agrária do país. Houve um incentivo à prática produtiva que trouxe agravos e consequências ao bioma da Amazônia pela intensa destruição e mesmo às populações migrantes que lutaram pela terra e hoje se encontram em meio a um espaço/tempo de esvaziamento da ruralidade, concentração de terra, renda e poder e desequilíbrio ambiental. Enfim, enfrentar e superar a crise instalada configura desafio às próximas gerações de camponeses que resistem, mesmo diante da ausência de políticas públicas e de assistência até a atualidade.

\section{REFERÊNCIAS}

ARCMAP, E. S. R. I. 10.5. 1. Redlands, CA: ESRI, 2017.

BARROSO, J. C. (org.) Mato Grosso: do sonho à utopia da terra. Cuiabá: EdUFMT, 2008.

BECKER, Bertha K. Geopolítica da Amazônia. Estudos Avançados, São Paulo, v. 19, n. 53, p. 71-86, abr. 2005. 
|O Projeto de Assentamento Conjunto Terranova I na borda meridional da Amazônia MatoGrossense: efeitos territoriais da ocupação|

|José Aldair Pinheiro | Aumeri Carlos Bampi | Carlos Alberto Franco da Silva |

BRASIL. Estatuto da Terra - Lei no 4.504, de 30 de novembro de 1964. Disponível em: <http://www.planalto.gov.br/ccivil 03/leis/L4504.htm>. Acesso em: 02 fev. 2020.

BRASIL. Código Florestal (1965). Brasília: Senado Federal, 2004.

BUBLITZ, J. Desmatamento Civilizador: a história ambiental da Colonização Europeia no Rio Grande do Sul (1824-1924). ENCONTRO DA ANPPAS, 3., 2006, Brasília. Anais... Brasília: ANPPAS, 2006.

CASTRO, S. P. [et al.]. A colonização oficial em Mato Grosso: "a nata e a borra da sociedade". Cuiabá: EdUFMT, 2002.

FARIA, A. M. M.; RIBEIRO, A. R; IRIGARAY, C T. J. H.; SILVA, C. J. Formação socioeconômica do estado de Mato Grosso. In: CASTRO, E. R.; CAMPOS, I. Formaçãao socioeconômica da Amazônia. Belém: NAEA, 2015. p. 321-400.

FERREIRA, J. C. V. Mato Grosso e seus municípios. 19. ed. Cuiabá: Secretaria de Estado da Educação; Ed. Buriti, 2001.

HAESBAERT, R. Região e rede regional "gaúcha": entre redes e territórios. Boletim Gaúcho de Geografia, v. 21, n. 1, p. 15-27, 1996.

MIRANDA, M. O papel da colonização dirigida na expansão da fronteira na Amazônia. In: BECKER, B. K; MIRANDA, M.; MACHADO, L. O. Fronteira Amazônica: questões sobre a gestão do território. Rio de Janeiro: UFRJ, 1990. p. 47-62.

PINHEIRO, J. A. Colonização e sustentabilidade: estudo de caso da Comunidade de Nova Guarita, MT. 2009. Dissertação (Mestrado em Ciências Ambientais) - Universidade Estadual do Mato Grosso, Cáceres, 2009.

PRODES - Projeto de Estimativa do Desmatamento da Amazônia. INPE. Disponível em: < http://www.dpi.inpe.br/prodesdigital/prodesmunicipal.php>. Acesso em: 07 dez. 2019.

PROJETO MAPBIOMAS - COLEÇÃO 4.1. Série anual de mapas de cobertura e uso de solo do Brasil. 2020.

RESENDE, M.; CURI, N.; LANI, J. L. Reflexões sobre o uso dos solos brasileiros. In: ALVAREZ, V. V. H.; SCHAEFER, C. E. G. R.; BARROS, N. F.; MELLO, J. W. V.; COSTA, L. M. (Ed.). Tópicos em ciência do solo. Viçosa-MG: Sociedade Brasileira de Ciência do Solo, 2002. v. 2. p. 593-644.

SOARES FILHO, B. S. Modelagem da dinâmica de paisagem de uma região de fronteira de colonização amazônica. 1998. 299 f. Tese (Doutorado em Engenharia de Transportes) - Universidade de São Paulo, São Paulo, 1998.

SCHWANTES, N. Uma cruz em Terra Nova. São Paulo: Scritta Oficial Editorial, 1989.

Como citar este artigo: 
|O Projeto de Assentamento Conjunto Terranova I na borda meridional da Amazônia MatoGrossense: efeitos territoriais da ocupação|

|José Aldair Pinheiro | Aumeri Carlos Bampi | Carlos Alberto Franco da Silva |

\section{ABNT}

PINHEIRO, J. A.; BAMPI, A. C.; FRANCO DA SILVA, C. A. O Projeto de Assentamento Conjunto Terranova I na borda meridional da Amazônia Mato-Grossense: efeitos territoriais da ocupação. InterEspaço: Revista de Geografia e Interdisciplinaridade, v. 6, e202005, 2020. Disponível em: <http://dx.doi.org/10.18764/2446-6549.e202005>. Acesso em: 25 jan. 2020.

\section{APA:}

Pinheiro, J. A., Bampi, A. C., \&Franco da Silva, C. A. (2020). O Projeto de Assentamento Conjunto Terranova I na borda meridional da Amazônia Mato-Grossense: efeitos territoriais da ocupação. InterEspaço: Revista de Geografia e Interdisciplinaridade, v. 6, e202005. Recuperado em 25 janeiro, 2020, de http://dx.doi.org/10.18764/2446-6549.e202005

\section{(c) creative}

This is an open access article under the CC BY Creative Commons 4.0 license.

Copyright (C) 2020, Universidade Federal do Maranhão.



